\title{
Mangrove habitats as nurseries: unique assemblages of juvenile fish in subtropical mangroves in eastern Australia
}

\author{
Pia Laegdsgaard, Craig R. Johnson* \\ Department of Zoology, The University of Queensland, St. Lucia, Queensland 4072, Australia
}

\begin{abstract}
A total of 53 species of juvenile fish were caught over a 2 yr study period in 2 mangrove lined estuaries in Moreton Bay, eastern subtropical Australia. Comparing juvenile fish communities among mangrove forests, seagrass beds and mudflats identified significant differences in species richness and abundances of juveniles. Seagrass communities comprised distinct species of resident and nonresident fish species of little economic importance. Mangrove forests and mudflats had many shared species (but mangrove forests were dominated by smaller or younger juveniles in greater abundances; Laegdsgaard unpubl. data). Mudflat habitats appear to be transition zones between juvenile and adult habitats. Only 4 species were exclusive to seagrass whereas 27 species were exclusive to the mangrove/mudflat habitat. Juveniles of 7 of the 10 commercially harvested fish species in Moreton Bay were found in greatest numbers in mangrove forests. Salinity, temperature and turbidity were similar in all habitats so could not account for differences in habitat choice of juvenile fish. Most juvenile fish in mangroves during summer were nonresidents and species richness and abundance were highest in summer and lowest in winter There were significant differences among sites and years in the numbers of species and individuals; however, the trends were similar and demonstrated clearly that mangrove sites within Moreton Bay play a more important role and have greater potential as nursery habitats than do adjacent habitats. Preferential selection of mangrove habitats by juvenile fish, particularly commercial species, indicates a need for conservation.
\end{abstract}

KEY WORDS: Mangrove - Seagrass - Mudflat - Nursery habitat - Juvenile fish - Community structure

\section{INTRODUCTION}

Mangrove forests are arguably unique in their function as nurseries and support species important to the fishing industry worldwide. Many fish species enter estuaries as postlarvae and juveniles after spending the larval stage in offshore waters where the adults spawn (Bell et al. 1984, Little et al. 1988). While the nursery role of mangroves is widely accepted for tropical and temperate mangrove habitats in the USA, Africa and Asia (Austin 1971, Wright 1986, Thayer et al. 1987, Little et al. 1988, Chong et al. 1990), few mangrove habitats in Australia have been similarly evaluated. Work in Australia has concentrated in the large mangrove forests of tropical Australia which contain

•E-mail: c.johnson@mailbox.uq.oz.au the majority of the mangrove flora species (Beumer 1978, Robertson \& Duke 1987, 1990, Blaber et al. 1989).

It is well established that adult and juvenile fish inhabit mangrove lined estuaries worldwide (Austin 1971, Blaber 1980, Yanez-Arancibia et al. 1980) yet few studies have evaluated the importance of mangrove habitats as nursery areas relative to adjacent habitats such as seagrass beds and mudflats that are also associated with estuarine areas. Seagrass beds are important nurseries for many species of fish and crustaceans (Middleton et al. 1984, Blaber et al. 1992, McNeil et al. 1992), and in many cases species assemblages in seagrass beds differ from those in nearby sand habitats (Pollard 1984, Ferrell \& Bell 1991, Blaber et al. 1992). Only Robertson \& Duke (1987) and Thayer et al. (1987) have undertaken meaningful comparisons of mangroves and proximal habitats, the former finding that 
mangroves in a north Queensland (Australia) estuary contained 4 to 10 times more fish than adjacent seagrass beds, whilst the latter recorded up to 32 times more fish in prop root environments than in surrounding seagrass habitats

Bell et al. (1984) and Potter et al. (1983) have indicated the potential of temperate mangrove habitats as nursery areas for juvenile fish, but comparisons among adjacent habitats have not been made in temperate or subtropical estuaries, and it is not possible to relate findings from tropical mangrove areas due to differences in environment and community composition (Cain \& Dean 1976, Thayer et al. 1987, Little et al. 1988, Chong et al. 1990). In general, temperate and subtropical mangrove systems harbour fewer species than tropical systems (Stephenson \& Dredge 1976. Quinn 1980, Thayer et al. 1987, Morton 1990).

Mangroves in the tropical north and temperate western and eastern regions of Australia have been shown to be valuable nursery areas for juvenile fish and crustaceans (Blaber 1980, Quinn 1980, Bell et al. 1984, Blaber et al. 1985, Robertson \& Duke 1987, Loneragan \& Potter 1990), but the nursery value of subtropical. ones has received little attention despite the increasing rate of development in these areas (Hyland \& Butler 1988). Reclamation and destruction of wetlands in Australia can be expected to lead to declines in associated fisheries as has already occurred in Asia (Field \& Dartnoll 1987).

This study evaluates mangrove areas within Moreton Bay, subtropical eastern Australia, as nursery sites for juvenile fish. Mangrove habitats are compared with adjacent seagrass and mudflat habitats, giving particular attention to species associated with nearby fisheries. Moreton Bay is a large, protected bay adjacent to a capital city (population 1.3 million), and sustains one of the most important fisheries resources of Queensland. The fishery produces $10 \%$ of the State's total volume of seafood, accounts for $33 \%$ of the recreational effort in the State, and the commercial catch alone generates A\$6 million at the retail level (Quinn 1993). However, substantial amounts $(19 \%)$ of mangrove habitat in the bay have already been reclaimed for development (Hyland \& Butler 1988), and in the face of increasing demand for real estate, the importance and uniqueness of the nursery function of these areas needs to be defined.

\section{MATERIALS AND METHODS}

Study sites. Juvenile fish communities in mangrove forests, seagrass beds and on open mudflats were sampled monthly from September 1991 until August 1993 at Deception Bay and Fisherman Island in Moreton

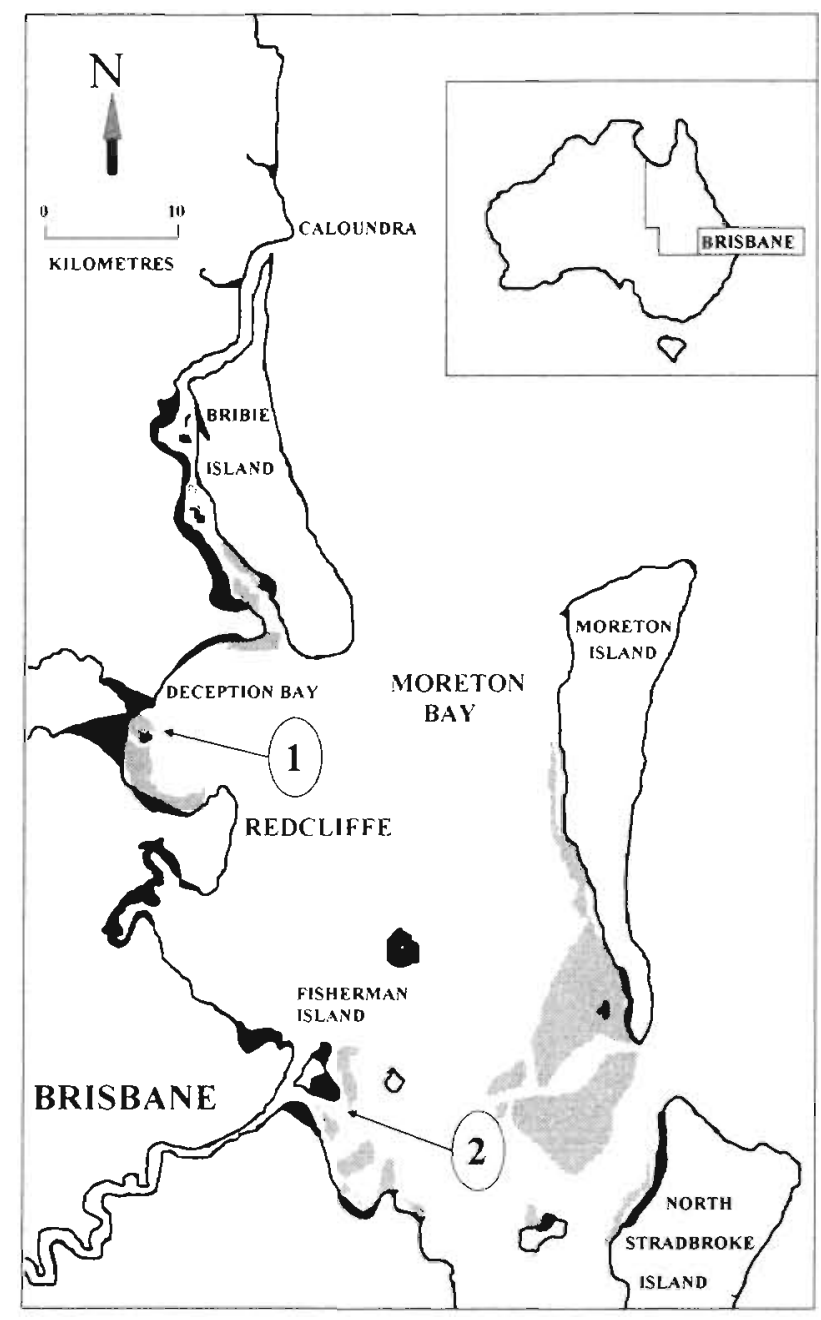

Fig. 1. Map of Moreton Bay showing the Deception Bay (1) and Fisherman Island (2) study sites. Dark filled areas indicate the extent of the mangrove habitat in the bay, whilst shaded areas show the positions of seagrass beds

Bay, South East Queensland, Australia (Fig. 1). The Deception Bay site is a fisheries habitat reserve but is subject to local recreational fishing. Fisherman Island, situated at the mouth of the Brisbane River, is the site of the Port of Brisbane and is a major industrial area.

Both sites support extensive stands of mangrove forest dominated by the grey mangrove Avicennia marina. The forests consist of mature trees up to $10 \mathrm{~m}$ in height and abundant younger trees up to $5 \mathrm{~m}$ in height. Algae and pneumatophores approximately $10 \mathrm{~cm}$ high cover the forest floor keeping the muddy substratum firm. Pneumatophores and algae extend in a 5 to $6 \mathrm{~m}$ wide fringe beyond the line of the mangrove forest. The substratum of the extensive mudflats consist of a mixture of coarse grained sand and fine grained mud. Seagrass beds are dominated by Zostera capricorni or Halophila ovalis, but mixed stands of sev- 
eral species can occur. In this study, samples were taken from $Z$. capricorni beds where blades were long and densely packed.

Tidal ranges are 0.1 to $2.5 \mathrm{~m}$ during a full monthly tidal cycle, and at low tide the forests drain completely and seagrass beds and mudflats become completely exposed. The forest at Deception Bay is broken by a large creek approximately $4 \mathrm{~m}$ wide which does not empty completely at low tide but is separated from the main body of water by a large sand bank.

Fish collection. Juvenile fish were distinguished on the basis of size, colouration and shape (given allometric changes in morphology with ontogenetic development) and were sampled on mudflats, in seagrass beds and amongst pneumatophores along the fringe of the mangrove forest using a pocket seine net $(6 \times 1.5 \mathrm{~m}$, $1 \mathrm{~mm}$ mesh size). The appropriate length of tow to optimise the number of species caught was determined from rarefaction curves (Fig. 2), which indicated that a tow of 20 paces was sufficient for each habitat. On each sampling occasion, 4 replicate seines were taken in each of the 3 habitats at both sites.

Juvenile fish in the mangrove forests (as distinct from the pneumatophore fringe) were sampled using trap nets $(8 \times 2 \mathrm{~m}, 1 \mathrm{~mm}$ mesh size) since it was not possible to seine through densely packed trees. At peak high tide, trap nets were set at the mouths of small tidal creeks draining the mangrove forest and left to catch fauna being swept out with the receding tide. Traps were emptied once the tide had ebbed. On each sampling occasion 4 replicate trap nets were set at each site. The area sampled by the trap nets was greater than that sampled by the seine net, and since it was not possible to get an exact measurement of this area, direct comparisons between seine and trap net samples were not possible

Sampling was conducted on the peak monthly high tides corresponding to the full moon. Traps were set during the midmorning high tides and seine samples usually collected on the outgoing tide of the same day. When possible the 2 sites were sampled on consecutive days. Captured juvenile and postlarval fish were preserved in $10 \%$ formalin/seawater solution.

Temperature, salinity and secchi depths were recorded in each habitat on each sampling occasion. Monthly rainfall data for the study period was provided by the Australian Bureau of Meteorology.

Analysis. Total abundances: Total abundances of all species pooled were analysed for yearly and seasonal differences (fixed effects) and between habitats (fixed effect) and sites (random effect) using a 4-way mixed model analysis of variance (ANOVA). Data were log transformed to stabilise variances. Due to differences in the sampling techniques, data from seine and trap nets were analysed separately.
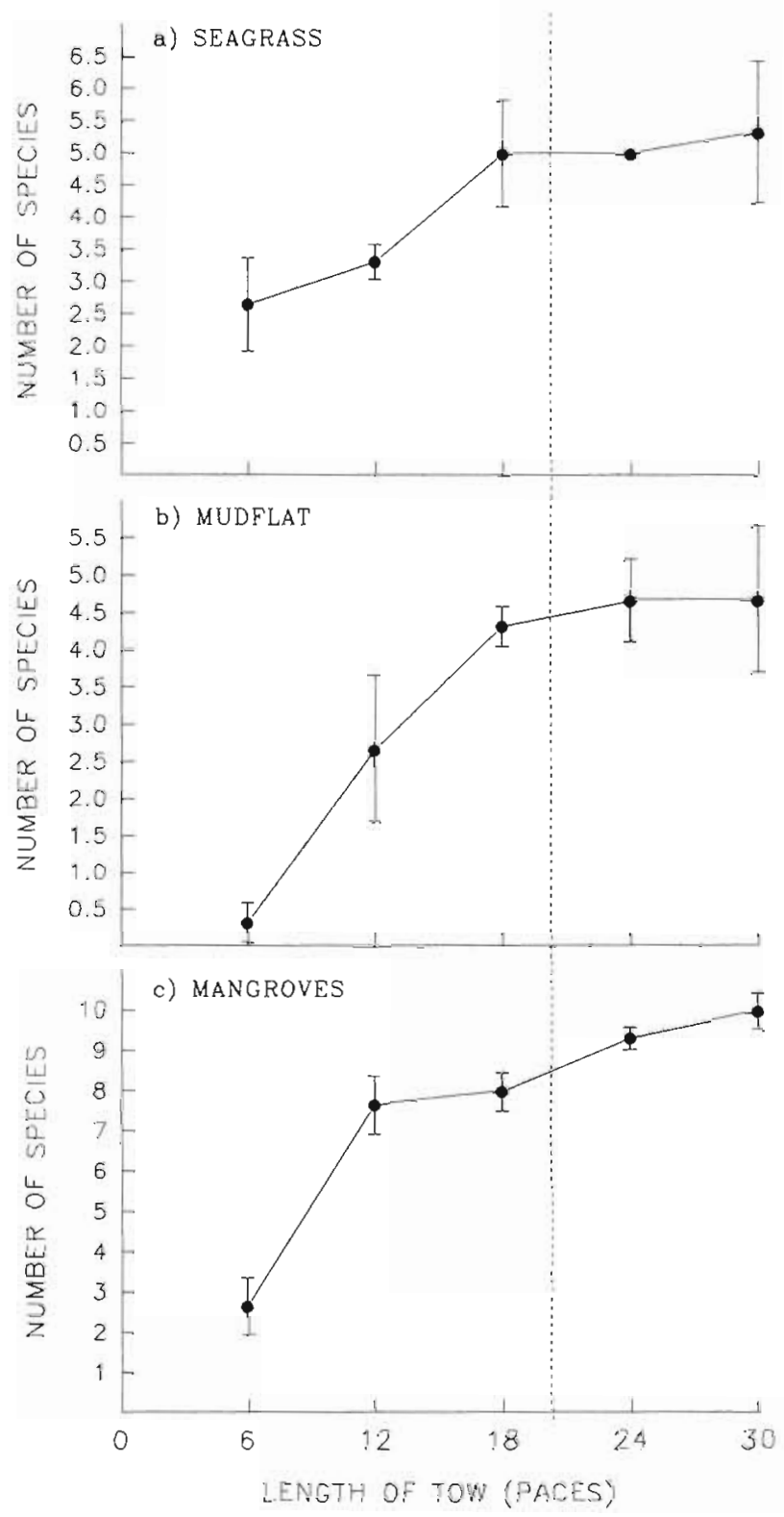

Fig. 2. Rarefaction curves for (a) seagrass, (b) mudflat and (c) mangrove habitats showing the number of species caught at various seine tow lengths (units $=$ paces). Points represent means of 4 replicate tows $\pm 1 \mathrm{SE}$. The length of tow used throughout the study ( $=20$ paces) is represented by the dotted line

Diversity: Shannon-Wiener indices were calculated for each season/site/habitat combination. Total abundances, pooling all replicates, were used and trap net and seine samples were treated separately.

Classification using binary data: Cochran's test, cluster analysis using Czechanowski's index (equivalent to the Bray-Curtis index with binary data) and multidimensional scaling (MDS) were used to compare among sites, seasons and habitats on the basis of presence or absence of species. Data from both 
seine and trap net samples were included in these analyses.

Classification using abundance data: To enable comparisons of seine and trap net data, which represent sampling of vastly different areas, it was necessary to standardise data to a sample size of 1000 . Differences among site, year, season and habitat were then analysed with cluster analysis and MDS based on Bray-Curtis dissimilarities using the unweighted pair group mean arithmetic (UPGMA) sorting strategy. These analyses were also undertaken on unstandardised data from seine samples.

MANOVA: Data standardised to a sample size of 1000 and including trap net samples were analysed using multivariate analysis of variance (MANOVA). Rare and resident species were excluded from the data set. Rare species were those for which $<10$ individuals were collected during the entire 2 yr study. Resident species are those that breed within that habitat and occur in the habitat year round as both adults and juveniles. A total of 21 species were included in the analysis.

Data were double square-root transformed to prevent abundant species from dominating the analysis.

Table 1 Field measurements for seasonal environmental parameters of temperature, salinity and turbidity in each habitat. SG: seagrass; MF: mudflat; M: mangrove; Sp: spring; S: summeri $A$ : autumn; $W$ : winter

\begin{tabular}{|c|c|c|c|c|c|c|c|}
\hline \multirow{2}{*}{$\begin{array}{l}\text { Para- } \\
\text { meter }\end{array}$} & \multirow[t]{2}{*}{ Season } & \multicolumn{3}{|c|}{ Deception Bay } & \multicolumn{3}{|c|}{ Fisherman Island } \\
\hline & & $S G$ & MF & $M$ & $\mathrm{SG}$ & MF & M \\
\hline \multirow{8}{*}{$\begin{array}{l}\text { Temp. } \\
\left({ }^{\circ} \mathrm{C}\right)\end{array}$} & Sp'91 & 23.6 & 22.3 & 23.1 & 22.6 & 23.9 & 22.5 \\
\hline & $S^{\prime} 91 / 92$ & 27 & 26.5 & 26.7 & 26.5 & 26 & 26.5 \\
\hline & $A^{\prime} 92$ & 21.7 & 22.3 & 23.3 & 22.5 & 23 & 22.6 \\
\hline & $W^{\prime} 92$ & 17.3 & 17.5 & 18 & 17.6 & 18 & 19.9 \\
\hline & Sp'92 & 20.6 & 21.9 & 21.5 & 22.3 & 21.5 & 22 \\
\hline & S'92/93 & 28 & 28.3 & 29 & 28 & 28.3 & 27.9 \\
\hline & $A^{\prime} 93$ & 22 & 20.6 & 21.6 & 20.5 & 21 & 22.3 \\
\hline & W'93 & 18.4 & 18 & 17.9 & 18 & 18 & 18.5 \\
\hline \multirow{8}{*}{$\begin{array}{l}\text { Salinity } \\
(\%)\end{array}$} & Sp'91 & 34.9 & 34.8 & 34.7 & 34.1 & 33.2 & 33.3 \\
\hline & $S^{\prime} 91 / 92$ & 32.2 & 31.7 & 31.8 & 27.3 & 25.6 & 24.7 \\
\hline & $A^{\prime} 92$ & 31.1 & 31.5 & 32.6 & 31 & 30.8 & 32.3 \\
\hline & W'92 & 35.9 & 35.8 & 36.1 & 34.8 & 35 & 35.1 \\
\hline & Sp'92 & 33.9 & 33.3 & 34.4 & 33.6 & 33.3 & 33.2 \\
\hline & $\mathrm{S}^{\prime} 92 / 93$ & 32.4 & 32.4 & 33.2 & 32.2 & 32.4 & 31.5 \\
\hline & $A^{\prime} 93$ & 34.2 & 33.9 & 342 & 33.3 & 33.2 & 32.8 \\
\hline & W'93 & 35.1 & 35.4 & 36.9 & 34.8 & 35.4 & 35.2 \\
\hline \multirow{8}{*}{$\begin{array}{l}\text { Secchi } \\
\text { depth } \\
\text { (cm) }\end{array}$} & $\mathrm{Sp} p^{\prime} 91$ & 81.9 & 86.4 & 77.2 & 83.8 & 85.6 & 58.1 \\
\hline & $\mathrm{S}^{\prime} 91 / 92$ & 68.2 & 76.3 & 76 & 84.3 & 73.3 & 46.7 \\
\hline & $A^{\prime} 92$ & 70.3 & 68 & 69.7 & 84.3 & 81.7 & 57.3 \\
\hline & W'92 & 70.7 & 78.3 & 66.7 & 71.7 & 70 & 62 \\
\hline & Sp'92 & 92.7 & 93 & 88.7 & 84 & 84 & 74 \\
\hline & $\mathrm{S}^{\prime} 92 / 93$ & 75.7 & 727 & 71 & 68 & 67 & 64.7 \\
\hline & $A^{\prime} 93$ & 817 & 81.7 & 78.7 & 101.7 & 96.3 & 94 \\
\hline & $w^{\prime} 93$ & 81.3 & 82 & 75.3 & 81.7 & 72.7 & 59.7 \\
\hline
\end{tabular}

This was done to allow less abundant species that may be more habitat specific to contribute equally to the analysis. To reduce dimensionality of the data, a principle components analysis (PCA) was conducted and the first 13 principle components, describing $95 \%$ of the total variation, were used in a 4 -way mixed model factorial MANOVA where site (random), year (fixed), season (fixed) and habitat (fixed) were the main effects. As recommended by Johnson \& Field (1993), Pillai's statistic was used to determine significance, data were also examined by Canonical Discriminant Analysis (CDA) and 95\% confidence ellipsoids calculated around centroids in reduced space. CDA conducted this way may be viewed as a graphical form of MANOVA (Johnson \& Field 1993).

\section{RESULTS}

\section{Physical conditions}

Differences in temperature, salinity and turbidity among habitats within sites were minimal (Table 1). Temperature varied strongly with season, rising to summer maxima of $27^{\circ} \mathrm{C}$ in $1991 / 92$ and $29^{\circ} \mathrm{C}$ in $1992 / 93$ with winter minima of $17^{\circ} \mathrm{C}$ in both years. Salinity varied between sites with a larger range evident at Fisherman Island (24 to $35 \%$ ) than at Deception Bay ( 31 to $36 \%$ )

Rainfall was much higher during summer and autumn of 1991/92 than at any other time during the study (Fig. 3). Total rainfall during the 1991/92 summer (December-February) was $740.2 \mathrm{~mm}$ compared to $315.8 \mathrm{~mm}$ for the $1992 / 93$ summer.

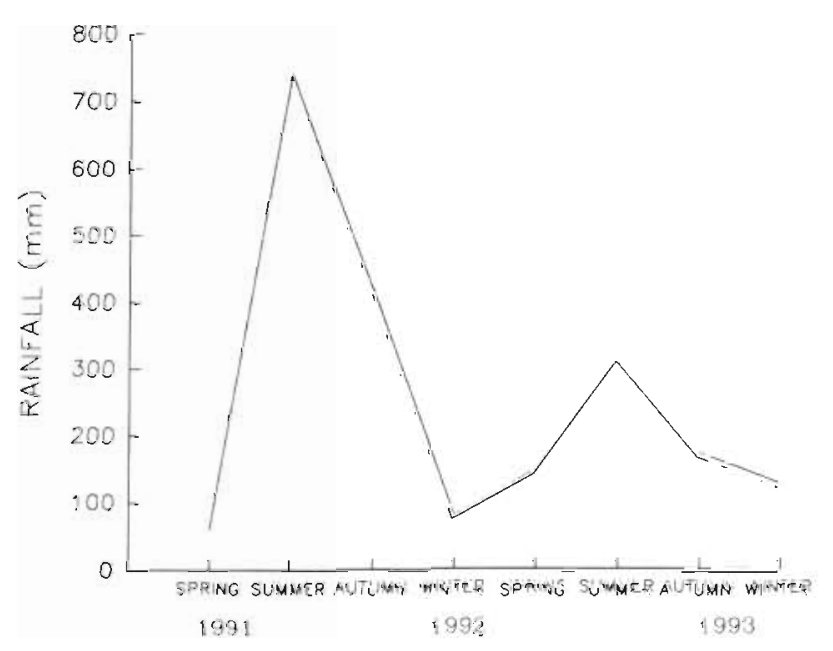

Fig. 3. Seasonal rainfall for the study period, spring 1991 to winter 1993 


\section{Community structure and seasonality}

Total abundances

A total of 23630 juvenile fish were caught at Deception Bay while Fisherman Island yielded 40442 individuals over the study period. In general, mean monthly catches in the mangrove and seagrass habitats at Fisherman Island were greater than at Deception Bay, except in winter when catches were uniformly low (Fig. 4a, b, d). There was a substantial difference between fish abundances in 1991/92 and 1992/93 in both seagrass and mangrove habitats at Fisherman Island. Catches in the mangroves were
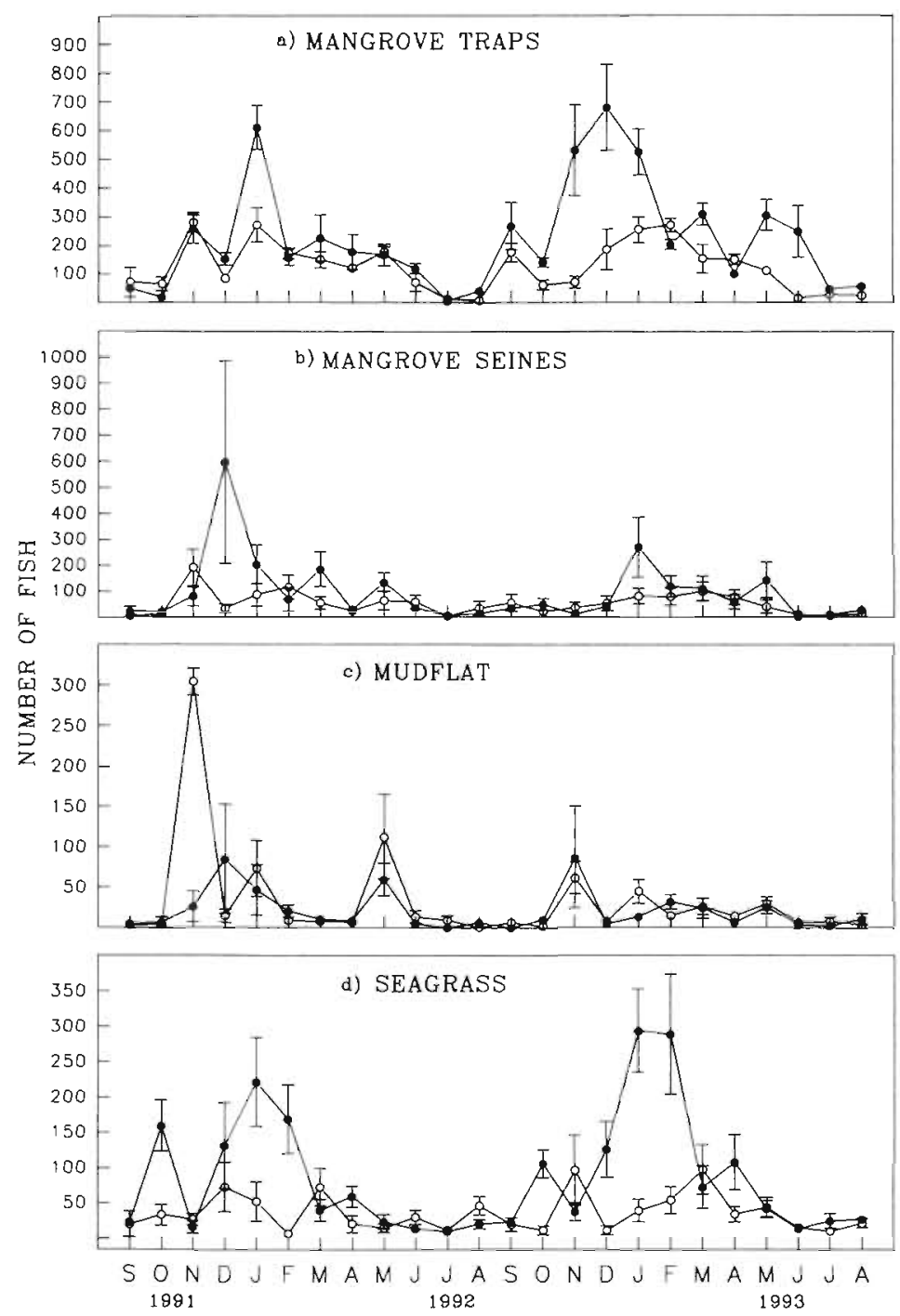

Fig. 4. Total monthly fish catches at Deception Bay (0) and Fisherman Island ( ). (a) Means from 4 replicate trap nets per month $\pm 1 \mathrm{SE}$ in the mangrove forest; (b) means from 4 replicate seines $\pm 1 \mathrm{SE}$ in the pneumatophore fringe, (c) means from 4 replicate seines \pm 1 SE on the mudflats, and (d) means from 4 replicate seines $\pm 1 \mathrm{SE}$ in the seagrass beds
13516 and 16669 for the first and second year respectively and catches in the seagrass were 3545 and 4673.

Peak mean abundances in the mangrove habitat occurred in the summer months of December and January (Fig. 4a, b) with lows in winter during July. The mudflat habitat yielded peak catches in November and December, but a second peak in May occurred in 1992 (Fig. 4c). Peak abundances in the seagrass habitat were recorded in the late summer months of January and February and poorest catches were in the winter months of June and July. Fish were present year round in the seagrass habitat and were more abundant in this habitat than in mangroves or on mudflats during winter (Fig. 4d). The clear seasonal pattern of fish abundance exhibited in the seagrass and mangrove habitats of Fisherman Island were less pronounced at the Deception Bay site (Fig. 4). These patterns yielded a significant site $\times$ habitat $\times$ year $\times$ season interaction in the analysis of data from seine nets (4-way ANOVA, $F=3.08, \mathrm{df}=6, \mathrm{p}<0.007$ ).

\section{Species richness}

Shannon-Wiener diversity indices failed to show any clear pattern for any site/habitat combination, so only the results for species richness are presented.

At Fisherman Island, the number of species in vegetated habitats reached a maximum during summer (seagrass) or autumn (mangroves), and decreased during winter (Fig. 5a, b, d). In contrast, there was no clear seasonal pattern in the mudflat habitat between the 2 years although a greater number of species were caught in the second year (Fig. 5c). Species richness was consistently higher in the mangrove habitat than in seagrass or mudflat areas.

Trends at Deception Bay were not as clear. The number of species caught in the seagrass habitat showed the most distinct seasonal pattern, being an increase in species richness in summer accompanied by a decrease in winter in both years, similar to that at Fisherman Island (Fig. 5d). The mudflat habitat showed no seasonal pattern with similar numbers of species being caught throughout the study period (Fig. 5c). Both seine and trap net data for the mangrove habitat indicated that slightly fewer species were caught in 1991/92 than 1992/93 but in the second year there was an autumnal increase in species richness similar to the pattern for Fisherman Island (Fig. 5a, b). 
A greater number of species were caught in mangrove habitats at Fisherman Island than at Deception Bay (Fig 5a, b). In all habitats at both sites the percentage of nonresident species in the population increased markedly during the summer months to outnumber residents by approximately 2:1 (Table 2). During winter the numbers of nonresident and resident species were approximately equal.
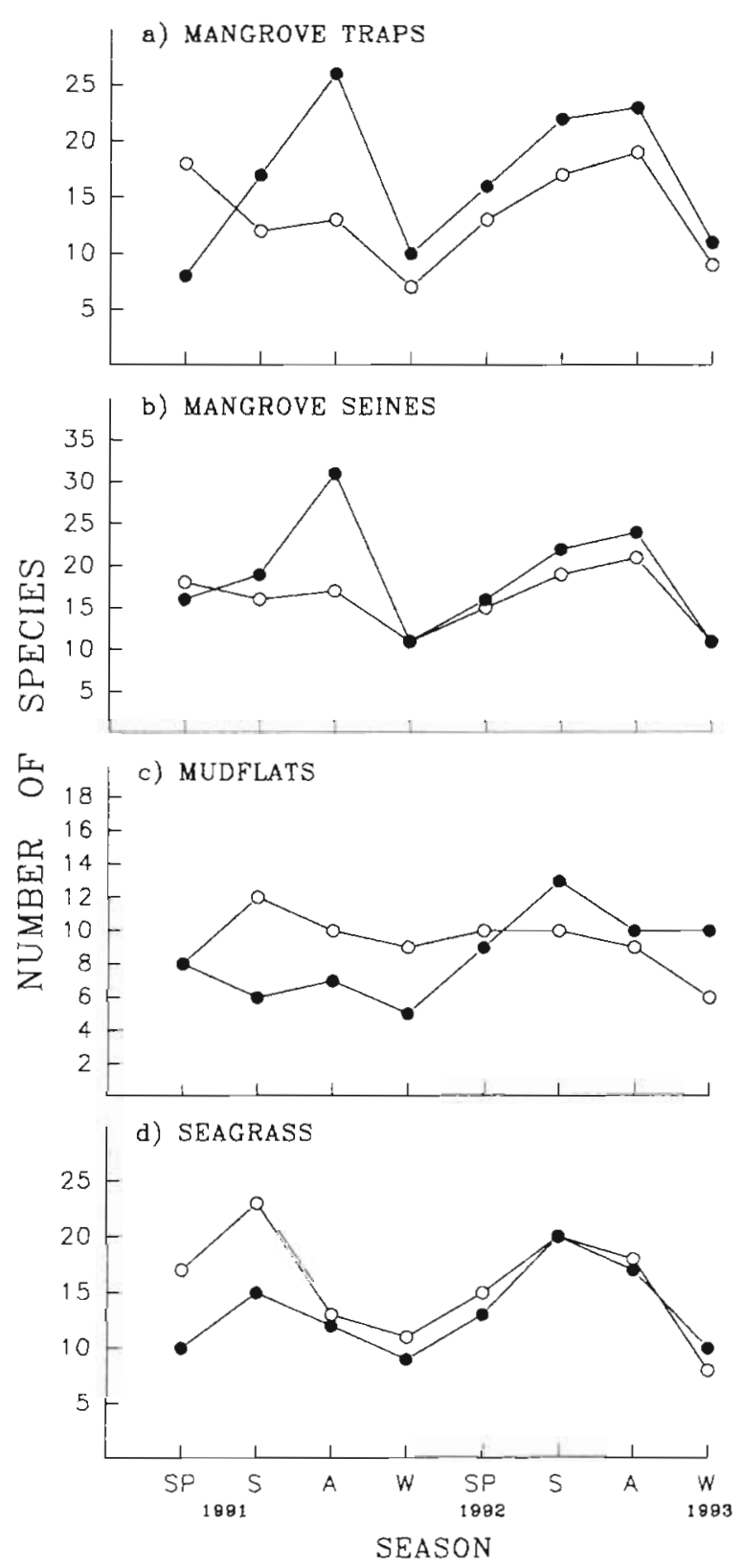

Fig. 5 Seasonal species richness at Deception Bay $(0)$ and Fisherman Island $(\bullet)$. Points represent total numbers of species caught in (a) mangrove forest trap nets, (b) pneumatophore fringe seines, (c) mudflat seines and (d) seagrass bed seines. Note that ordinate scales differ among habitat graphs
Table 2. Numbers and proportions (\% in parentheses) of resident versus nonresident species in summer (S) and winter $(W)$ in each habitat from total number of species at Deception Bay (DB) and Fisherman Island (FI)

\begin{tabular}{|c|c|c|c|c|c|c|}
\hline & \multicolumn{2}{|c|}{ Seagrass } & \multicolumn{2}{|c|}{ Mudflat } & \multicolumn{2}{|c|}{ Mangrove } \\
\hline & DB & FI & $\mathrm{DB}$ & FI & $\mathrm{DB}$ & FI \\
\hline \multicolumn{7}{|c|}{ Residents } \\
\hline $\mathrm{S}$ & $4(7)$ & $4(7)$ & $2(4)$ & $3(5)$ & $4(8)$ & $4(8)$ \\
\hline W & $3(5)$ & $3(5)$ & $2(4)$ & $2(4)$ & $4(7)$ & $3(6)$ \\
\hline \multicolumn{7}{|c|}{ Nonresidents } \\
\hline S & $10(19)$ & $8(16)$ & $6(11)$ & $4(8)$ & $8(15)$ & $11(20)$ \\
\hline W & $3(6)$ & $3(6)$ & $3(6)$ & $3(6)$ & $4(8)$ & $5(10)$ \\
\hline
\end{tabular}

\section{Habitat comparison}

Cluster analysis and MDS on standardised abundances (data from both seine and trap net samples) of species in each habitat/site/season combination showed that seagrass communities are clearly distinct from the others, and there is reasonable distinction among mangrove and mudflat communities (Fig. 6). Species assemblages in terms of presence/absence of species were significantly different among habitats (Cochran's test, $t=36.1, \mathrm{df}=5, \mathrm{p}<0.001$ ), with the seagrass community being significantly different to the others, but differences among mangroves and mudflats were not significant. Czechanowski's index gave comparable results.

Seagrass communities at Deception Bay were clearly separated from those at Fisherman Island (Fig. 6), and the difference in terms of species presence/absence was significant (Cochran's test, $t=6.4, \mathrm{df}=1, \mathrm{p}<0.01$ ). The 2 sites within the mudflat and mangrove habitats show a degree of overlap (Fig. 6) and species assemblages did not differ significantly between sites.

The MANOVA on standardised data (data from both seine and trap net samples) showed a significant site $x$ habitat $\times$ year $\times$ season interaction $(F=3.81$, df $=78, \mathrm{p}<$ 0.0001 ) and the CDA demonstrated the nature of this interaction (Fig. 7). During 1991/92 the fish assemblages in mangroves and seagrass were distinct from each other, regardless of site or season. The fish on mudflats were more similar in community composition to those in seagrass in winter than to any other habitat/season combination. In mangroves and seagrass beds there were differences depending on site and season whereas the community composition of fish on mudflats was similar at both sites in all seasons. The pattern in 1992/93 demonstrated some variations on the pattern just described mangrove communities remained distinct to those in other habitats at Fisherman Island and showed similarities to summer mudflat communities at Deception Bay. A clear seasonal shift was evident in the mangrove habitat. 


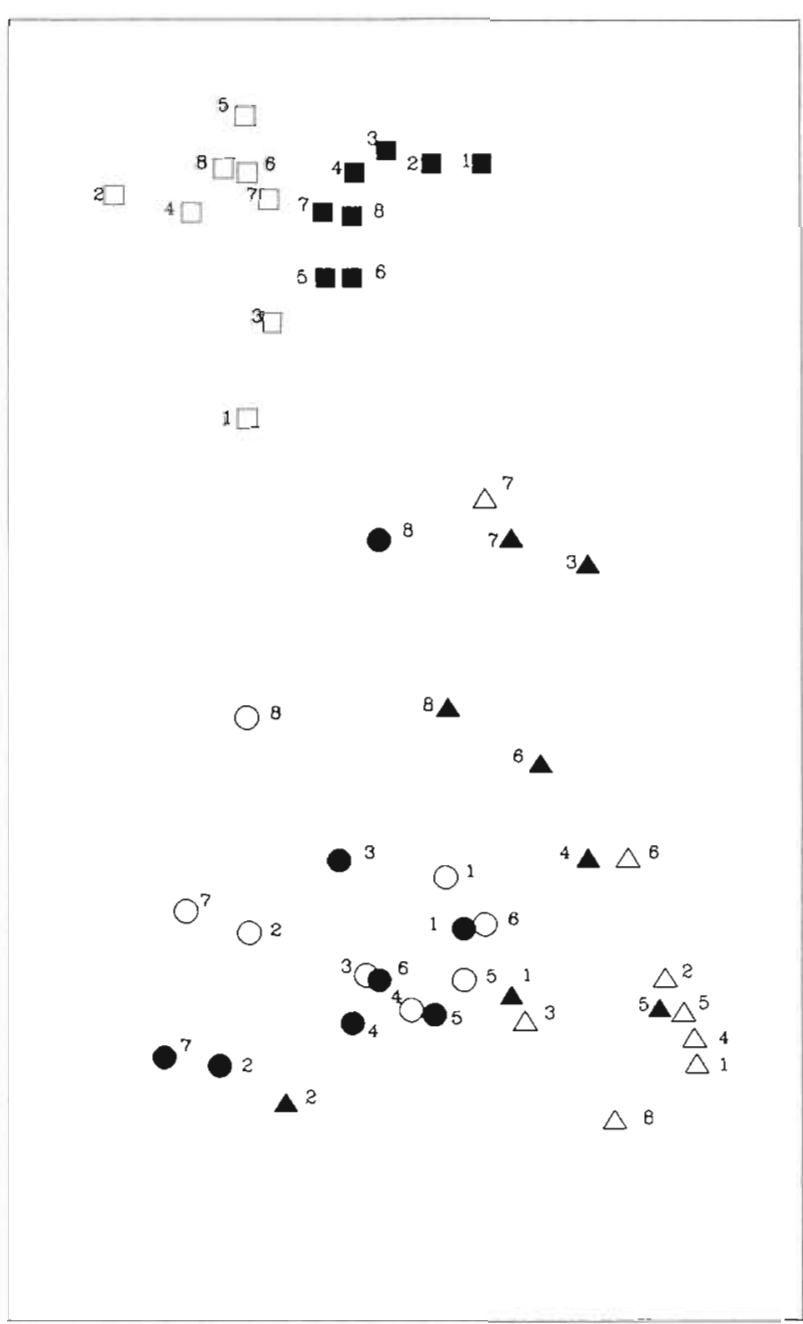

Fig. 6. Multidimensional scaling (MDS) diagram showing relationships between habitats and sites (stress $=0.03$ ). Seasons from spring 1991 to winter 1993 are represented by the numbers 1 to 8 . Deception Bay: $(\square)$ seagrass, $(\Delta)$ mudflat, (O) mangrove; Fisherman Island: (ロ) seagrass, (A) mudflat, (-) mangrove

that was notably similar between sites. Also, mudflat and seagrass communities were more similar to each other than in the previous year. Seasonal differences were smail on the mudflats at Fisherman Island and in seagrass beds at Deception Bay in 1992/93.

\section{Site and habitat specificity}

A total of 53 species of juvenile fish were captured in the 2 yr study period (Table 3 ). The 28 dominant species are important to the fishing industry as either commercial catch, bait fish or recreational fishing (Table 3) and of these 21 were nonresidents, occurring only as juveniles in the 4 habitats. There were 9 site-specific species, 6 found only at Fisherman Island and 3 found exclusively
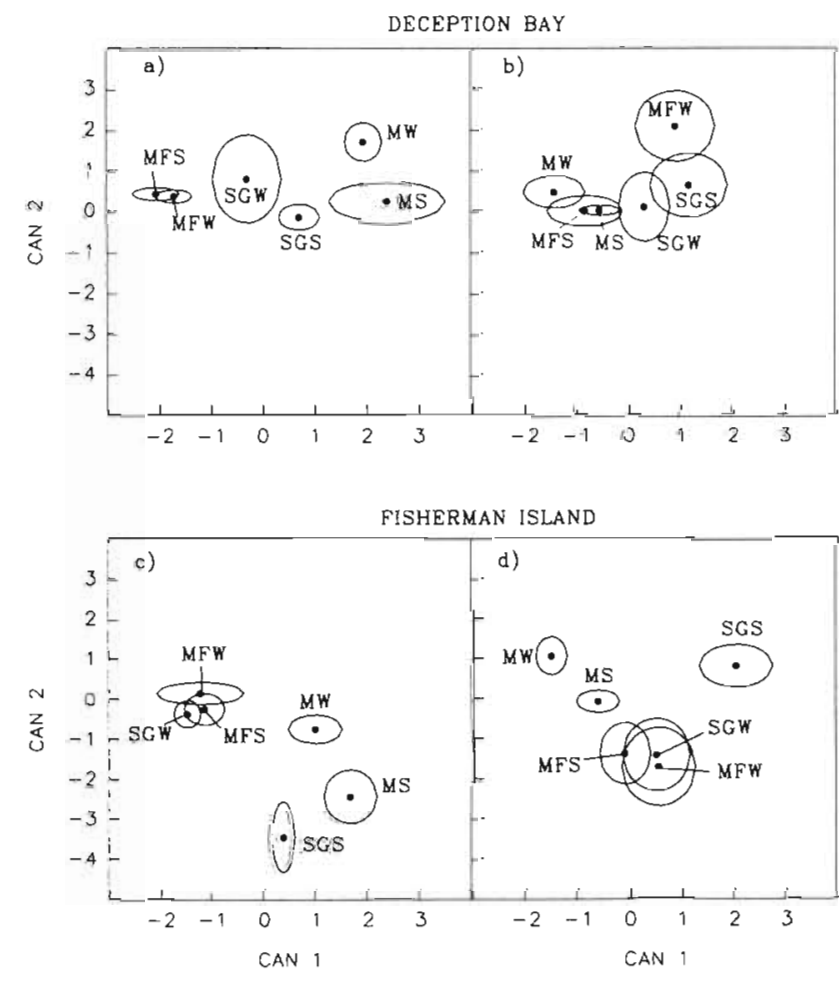

Fig. 7 Canonical Discriminate Analysis (CDA), represented by 4 diagrams, showing relationships between habitats (SG: seagrass; MF: mudflats; $M$ : mangroves) in summer (S) and winter (W), at Deception Bay (a) 1991-92, (b) 1992-93 and Fisherman Island (c) 1991-92, (d) 1992-93. Points are group centroids within $95 \%$ confidence ellipsoids. CAN1, CAN2: canonical axes 1 and 2

at Deception Bay. A total of 23 species occurred to some extent in all 4 habitats. In general, there were greater overlaps in species distributions between mangroves and mudflats than other habitat combinations. Overall, 27 of the total 53 species and 17 of the 28 dominant species occurred exclusively in mangroves and/or mudflats, with another 9 much more common in mangroves and on mudflats than in seagrass (Table 3 ). The 3 species of whiting, Sillago maculata, S. ciliata and S. analis, were the most abundant species present during the study and were exclusive to mudflats and mangroves.

Two species were exclusive to the mudflats (Table 4), the rare tongue sole Paraplagusia guttata and the abundant dragonet Callionymus calcaratus. The mangrove habitat contained a total of 14 species unique to the habitat, but the majority of these were rare (Table 4) although the longtom Tylosurus sp. occurred commonly. Tailor Pomatomus saltator were also common but specific to Deception Bay. Fisherman Island also had 4 site-specific mangrove species, 3 of which were common, namely flounder Pseudorhombus jenynsii and the scats Selenotoca multifasciata and Scatophagus argus. In total, 7 species were specific to 
Table 3. Abundance status of all species caught in each habitat at each study site. SG: seagrass; MF: mudflat ${ }_{i}$ PN: pneumatophore fringe; $M$ : mangrove forest. Due to differences in sampling gear, specles were scored as: ( ) absent; ( $\mathrm{r}$ ) very rare, $<5$ indıviduals caught total $(+)$ rare $_{1}<10$ individuals caught total $L_{i}(++)$ common, appearing $1 \mathrm{n}$ most samples; $(+++)$ abundant, large numbers in most samples. "Fish species important to the fishing industry as bait fish, commercial catch or recreational catch

\begin{tabular}{|c|c|c|c|c|c|c|c|c|}
\hline \multirow[t]{2}{*}{ Species } & \multicolumn{4}{|c|}{ Deception Bay } & \multicolumn{4}{|c|}{ Fisherman Island } \\
\hline & SG & $\mathrm{MF}$ & PN & M & $\mathrm{SG}$ & MF & PN & M \\
\hline Torguiener squamicauda (Ogilbi, 1911) & + & ++ & $\mathrm{r}$ & $r$ & & ++ & $\mathrm{r}$ & $\mathrm{r}$ \\
\hline Marylina pleurosticta (Gunther) & + & & ++ & +++ & +++ & ++ & ++ & +++ \\
\hline Tetractenos haniltoni (Gray \& Richardson, 1843) & +++ & +++ & +++ & +++ & +++ & +++ & $t+t$ & +++ \\
\hline Arothron hispidis (Linnaeus, 1758) & ++ & & · & & ++ & $\cdot$ & & $\cdot$ \\
\hline Selenotoca multifasciata (Richardson) & $\cdot$ & . & . & . & $\cdot$ & & ++ & ++ \\
\hline Scatophagus argus (Linnaeus) ${ }^{\bullet}$ & $\cdot$ & & $\cdot$ & & & & +++ & ++ \\
\hline Stolephorus carpentariae (DeVis, 1882) & ++ & $+t$ & +++ & $+t+$ & r & + & +++ & +++ \\
\hline Eristhmus lepturus (Gunther, 1864) & . & - & $\cdot$ & & & . & & I \\
\hline Tylosurus sp. & . & - & ++ & ++ & & $\cdot$ & ++ & ++ \\
\hline Arramphus sclerolepis Gunther, $1866^{\circ}$ & $\mathrm{r}$ & ++ & ++ & ++ & r & ++ & ++ & ++ \\
\hline Hyporhamphus ardelio (Whitley, 1931) & ++ & ++ & ++ & ++ & + & ++ & + & $r$ \\
\hline Atherinomorus ogilbyi Whitley, $1930^{\circ}$ & $r$ & ++ & ++ & ++ & $\cdot$ & $+t$ & ++ & ++ \\
\hline Platycephalus fuscus Cuvier, $1829^{\bullet}$ & + & $\mathrm{r}$ & ++ & +++ & +++ & $\mathrm{r}$ & ++ & +++ \\
\hline Platycephalus indicus (Linnaeus) " & $\cdot$ & . & $\cdot$ & r & $\cdot$ & $\cdot$ & r & + \\
\hline Ambassis marianus (Gunther) & ++ & r & +++ & +++ & +++ & ++ & +++ & +++ \\
\hline Gerres ovatus Gunther" & $r$ & $\mathrm{r}$ & +++ & +++ & + & +++ & +++ & +++ \\
\hline Acanthopagrus australis (Owen, 1853)" & ++ & $\mathrm{r}$ & ++ & +++ & +++ & ++ & +++ & +++ \\
\hline Mugil georgii (Ogilby) & $\mathrm{r}$ & + & +++ & +++ & $\cdot$ & & +++ & +++ \\
\hline Liza argentea (Quoy \& Gaimard) " & r & ++ & +++ & +++ & . & + & +++ & +++ \\
\hline Mugil sp. & $\mathrm{r}$ & ++ & ++ & +++ & . & . & $\cdot$ & $\cdot$ \\
\hline Sphyraena obtusata Cuvier, $1829^{\circ}$ & + & $\mathrm{r}$ & ++ & ++ & r & . & & $\mathrm{r}$ \\
\hline Pseudorhombus jenynsil (Bleeker, 1855)" & . & & . & & & & & ++ \\
\hline Paraplagusia guttata (Macleay, 1878$)^{\circ}$ & & r & . & & & . & & , \\
\hline Synaptura nigra Macleay, $185^{\circ}$ & & & . & & . & . & $\mathrm{r}$ & + \\
\hline Gambusia affinis (Baird \& Gerard) & . & & $\cdot$ & & & & r & + \\
\hline Sillago ciliata Cuvier & & +++ & +++ & +++ & & +++ & +++ & $t+t$ \\
\hline Sillago maculata Quoy \& Gaimard" & . & +++ & +++ & +++ & . & +++ & +++ & $t+t$ \\
\hline Sillago analis Whitley" & . & ++ & ++ & ++ & . & ++ & ++ & ++ \\
\hline Callionymus calcaratus & & ++ & & $\cdot$ & $\cdot$ & $+t$ & $\cdot$ & \\
\hline Family Gobiidae & +++ & ++ & +++ & +++ & +++ & +++ & +++ & +++ \\
\hline Prionobutis microps (Weber) & $\cdot$ & & & r & $\cdot$ & & $\cdot$ & r \\
\hline Butis butis (Hamilton-Buchanan) & $\cdot$ & & & r & $\cdot$ & & r & + \\
\hline Gobiopterus semivestitus (Munro, 1949) & +++ & ++ & +++ & +++ & +++ & +++ & +++ & +++ \\
\hline Upeneus tragula Richardson, $1846^{\circ}$ & r & $\cdot$ & & $\cdot$ & + & & $\cdot$ & $\cdot$ \\
\hline Centropogon a ustralls (Shaw, 1790) & +++ & & & . & ++ & & . & . \\
\hline Bathyaploactis curtensis & r & . & & . & & & . & \\
\hline Siganus spinus (Linnaeus) ${ }^{*}$ & ++ & . & - & $\cdot$ & r & . & . & $\cdot$ \\
\hline Pelates quadrilineatus (Bloch, 1790) ${ }^{\circ}$ & +++ & + & ++ & + & +++ & $\mathrm{r}$ & + & $+t$ \\
\hline Terapon jarbua (Forskal) & & - & ++ & +++ & & & r & $r$ \\
\hline Petroscirtes lupus (DeVis, 1886) & +++ & & & $\cdot$ & $+t$ & . & . & \\
\hline Meuschenia trachylepis (Gunther, 1870) & ++ & & & & r & . & . & \\
\hline Monocanthus chinensis (Osbeck, 1765) & ++ & & $\mathrm{r}$ & & ++ & . & r & $\mathrm{r}$ \\
\hline Microcanthus strigatus (Cuvier, 1831) & ++ & & $\mathrm{r}$ & & r & . & $\mathrm{r}$ & \\
\hline Family Syngnathidae & +++ & & . & r & +++ & & + & +++ \\
\hline Humantura uarnak (Forskal, 1755) & & & $\mathrm{r}$ & & & & I & \\
\hline Pseudocaranx dentex (Bloch \& Schneider, 1801) & $\mathrm{r}$ & + & + & + & r & $\mathrm{r}$ & + & + \\
\hline Spratellordes gracilis Bleeker & r & r & + & + & $\mathrm{r}$ & + & ++ & ++ \\
\hline Lutjanus russeli (Bleeker) & & & & r & . & & $\cdot$ & r \\
\hline Pomatomus saltator (Linnaeus, 1766$)^{\circ}$ & & & + & r & & & . & \\
\hline
\end{tabular}

the seagrass habitat (Table 4 ) including the abundant resident blenny species Petroscirtes lupus. Of the nonresident species, 3 were highly abundant, the stars and stripes toad Arothron hispidis, fortescue Centropogon australis and spinefoot Siganus spinus
Species comparisons

Results from separate 4-way ANOVAs on the 21 species used in the MANOVA are given in Table 5. For those species not restricted to 1 site or habitat, the 
Table 4. Numbers of exclusive species present in mangrove, mudflat and seagrass at Deception Bay (DB) and Fisherman Island (FI). Tot: total number of exclusive species across both sites

\begin{tabular}{|lcccccccccc|}
\hline & \multicolumn{1}{c}{ Mangrove } & \multicolumn{4}{c}{ Mudflat } & \multicolumn{3}{c|}{ Seagrass } \\
& DB & FI & Tot & DB & FI & Tot & DB & FI & Tot \\
& & & & & & & & & & \\
Nonresident & & & & & & & & & \\
$\quad$ Rare & 3 & 6 & 6 & 1 & 0 & 1 & 1 & 3 & 1 \\
$\quad$ Common & 2 & 4 & 5 & 1 & 1 & 1 & 4 & 2 & 4 \\
Resident & & & & & & & & & \\
$\quad$ Rare & 3 & 3 & 3 & 0 & 0 & 0 & 1 & 0 & 1 \\
Common & 0 & 0 & 0 & 0 & 0 & 0 & 1 & 1 & 1 \\
Total & 8 & 13 & 14 & 2 & 1 & 2 & 7 & 6 & 7 \\
\hline
\end{tabular}

nature of the significant interactions is shown in different periods of presence and absence throughout the years at the 2 sites (Figs. $8 \& 9$ ).

Selenotoca multifasciata and Scatophagus argus were site and habitat specific to the mangroves of Fisherman Island and were present during summer and autumn and absent at all other times. Terapon jarbua occurred only in mangrove habitats and was common at Deception Bay in winter whilst rare at Fisherman Island at any time of year. Callionymus calcaratus was common but occurred only on mudflats during summer and autumn at Deception Bay and during spring, sum- mer and winter at Fisherman Island. Platycephalus fuscus showed no distinct peak in abundance at either site but there were greater abundances of this species in the seagrass at Fisherman Island (Fig. 8). Stolephorus carpentariae and Mugil georgii show an autumn peak in abundance in the mangrove habitat at Fisherman Island whilst in other habitats these species have relatively even seasonal abundances (Fig. 8). M. georgii was habitat specific to mangroves at Fisherman Island but occurred in all habitats at Deception Bay; its abundances were, in general, lower at Deception Bay and an autumn peak was not evident (Fig. 9). At Deception Bay $S$. carpentariae had an autumn peak in the mangrove habitat in 1991/92 and a summer and autumn peak in 1992/93 (Fig. 9). There was an absence in winter of Arramphus sclerolepis, Hyporhamphus ardelio and Gerres ovatus at both sites (Figs. $8 \& 9$ ) and $S$. carpentariae was absent during winter at Deception Bay (Fig. 9) while $P$. fuscus was absent during winter only at Fisherman Island (Fig. 8).

Greater total abundances of Mugil georgii and Gerres ovatus were found at Fisherman Island than Deception Bay whilst abundances of Stolephorus carpentariae were greatest at Deception Bay. Liza argentea was most abundant in mangrove habitats and peak abundances were recorded in spring at Deception Bay (Fig. 9). At Fisherman Island only 1 notable peak occurred, in the 1991/92 summer (Fig. 8). Atheri-

Table 5. Results from 4-way ANOVAs on the 21 species used in the MANOVA. Results are only presented for the highest order interaction that is significant; $F$-values and their significance are indicated; $\cdots p<0.0001,{ }^{\prime} p<0.001, " p<0.01$, ns (not significant) $p>0.05$. ST: site; S: season; H: habitat; $Y$ year

\begin{tabular}{|c|c|c|c|c|c|c|}
\hline \multirow[t]{2}{*}{ Species } & \multicolumn{6}{|c|}{ Source } \\
\hline & $\begin{array}{c}\mathrm{ST} \times \mathrm{S} \times \mathrm{H} \times \mathrm{Y} \\
\mathrm{df}=6\end{array}$ & $\begin{array}{c}\mathrm{S} \times \mathrm{H} \times \mathrm{Y} \\
\mathrm{df}=6\end{array}$ & $\begin{array}{c}\mathrm{ST} \times \mathrm{S} \times \mathrm{H} \\
\mathrm{df}=6\end{array}$ & $\begin{array}{l}\mathrm{ST} \times \mathrm{S} \\
\mathrm{df}=3\end{array}$ & $\begin{array}{l}H \times Y \\
d f=2\end{array}$ & $\begin{array}{c}S \\
d f=1\end{array}$ \\
\hline Selenotoca multifasciata & $5.0 \cdots$ & - & - & - & - & - \\
\hline Scatophagus argus & $6.7^{\cdots}$ & - & - & - & - & - \\
\hline Terapon jarbua & $2.5^{\circ}$ & - & - & - & - & - \\
\hline Callionymus calcaratus & $4.1^{\cdots}$ & - & - & - & - & - \\
\hline Platycephalus fuscus & $2.6^{\bullet}$ & - & - & - & - & - \\
\hline Stolephorus carpentariae & $5.0^{\cdots}$ & - & - & - & - & - \\
\hline Mugil georgii & $3.6^{\cdots}$ & - & - & - & - & - \\
\hline Arramphus sclerolepis & $3.4^{\cdots}$ & - & - & - & - & - \\
\hline Hyporhamphus ardelio & $4.5^{\cdots}$ & - & - & - & - & - \\
\hline Gerres ovatus & $5.7 \cdots$ & - & - & - & - & - \\
\hline Liza argentea & $3.6^{\cdots}$ & - & - & - & - & - \\
\hline Atherinomorus ogilbyi & $4.8^{\cdots}$ & - & - & - & - & - \\
\hline Sphyraena obtusata & $3.5 \cdots$ & - & - & - & - & - \\
\hline Sillago spp. & $0.9 \mathrm{~ns}$ & $8.7^{\cdots}$ & $1.4 \mathrm{~ns}$ & - & - & - \\
\hline Monacathus chinensis & $0.4 \mathrm{~ns}$ & $1.9 \mathrm{~ns}$ & $2.2^{\circ}$ & - & - & - \\
\hline Acanthopagrus australis & $2.1 \mathrm{~ns}$ & $3.7 \mathrm{~ns}$ & $2.8 \cdot$ & - & - & - \\
\hline Siganus spinus & $1.8 \mathrm{~ns}$ & $0.9 \mathrm{~ns}$ & $5.3^{\cdots}$ & - & - & - \\
\hline Torguiener squamicauda & $2.0 \mathrm{~ns}$ & $2.6 \mathrm{~ns}$ & $2.5^{\cdot}$ & - & - & - \\
\hline Centropogon australis & $1.8 \mathrm{~ns}$ & $1.5 \mathrm{~ns}$ & $1.2 \mathrm{~ns}$ & $7.3 \cdots$ & $22.6^{\circ}$ & - \\
\hline Pelates quadrilineatus & $0.7 \mathrm{~ns}$ & $0.1 \mathrm{~ns}$ & $0.1 \mathrm{~ns}$ & $0.0 \mathrm{~ns}$ & $0.0 \mathrm{~ns}$ & $48.5^{*}$ \\
\hline Arothron hispidis & $1.3 \mathrm{~ns}$ & $0.8 \mathrm{~ns}$ & $0.4 \mathrm{~ns}$ & $0.6 \mathrm{~ns}$ & $15.5 \mathrm{~ns}$ & $0.5 \mathrm{~ns}$ \\
\hline
\end{tabular}



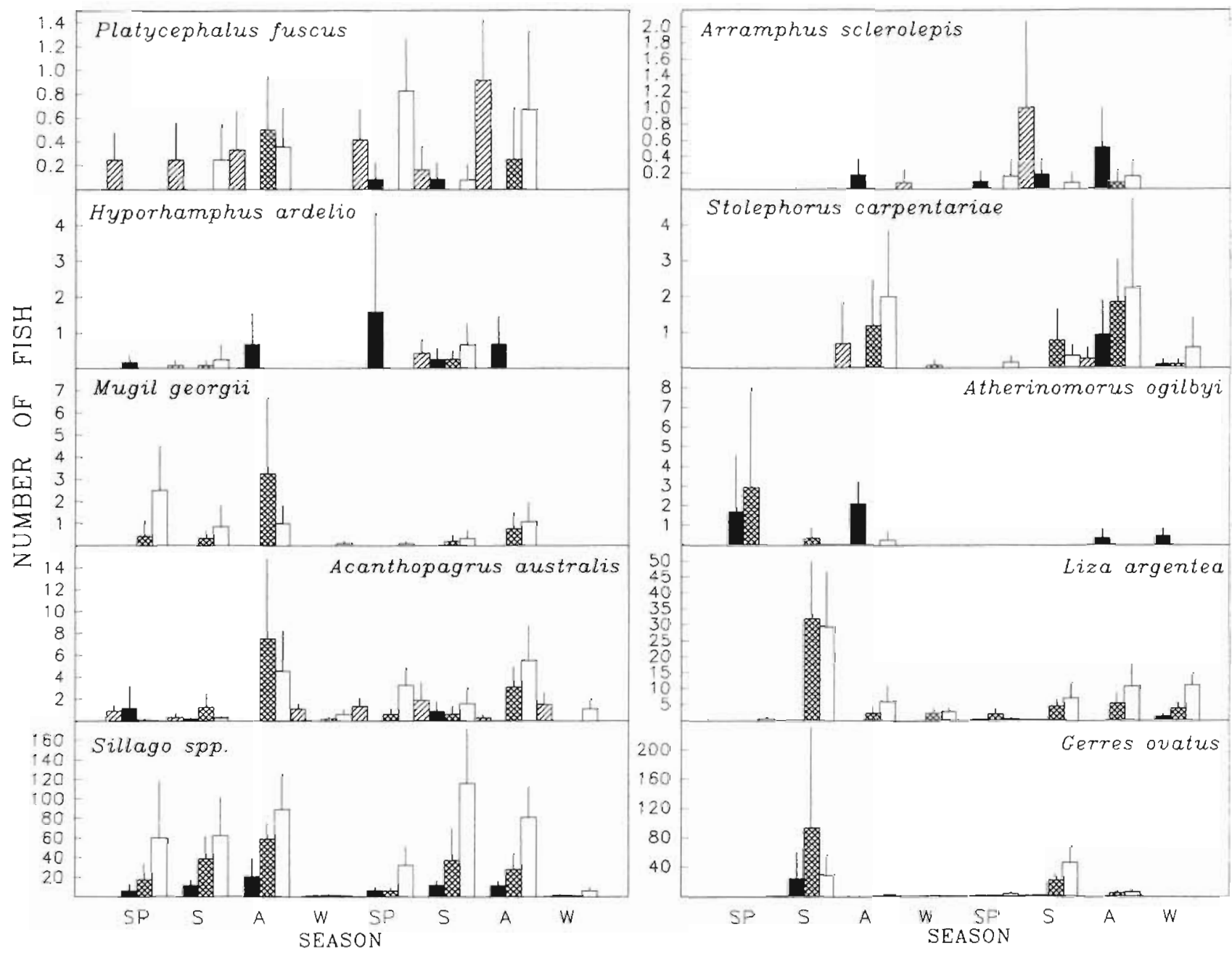

Fig. 8. Mean seasonal abundances \pm 1 SF for the 10 most abundant species at Fisherman Island that were not restricted to 1 habitat. Diagonal lines: seagrass; solid: mudflat; cross hatch: pneumatophores; empty: mangrove forest

nomorus ogilbyi was most common on mudflats and mangroves and was present throughout the study at Deception Bay except in summer (Fig 9). However, abundances of this species at Fisherman Island were high only in spring 1992/92 (Fig. 8)

Sillago spp. occurred in similar total abundances at both sites, but were not caught in the seagrass habitat at either site (Figs. 8 \& 9). Abundances were greater in the mangrove habitats and a summer peak was observed in 1992/93 only. Abundances were low in the winters of both years (Figs. $8 \& 9$ )

Monacanthus chinensis, Acanthopagrus australis and Siganus spinus were more abundant at Deception Bay than Fisherman Island. S. spinus was specific to seagrass, $M$. chinensis to seagrass and mangroves while A. australis occurred in all habitats but was more abundant in mangroves. $S$. spinus had summer peaks in abundance at both sites whilst $A$. australis and $M$. chinensis had autumn peaks especially in the mangrove habitats at Fisherman Island, this peak was not evident at Deception Bay.

Centropogon australis appeared throughout the 2 yr with peaks in abundance at Fisherman Island during summer and lows in winter. At Deception Bay abundances were fairly even across the year except for a drop in winter

Pelates quadrilineatus was encountered in all 3 habitats, and it was the most abundant fish in seagrass beds. Individuals of this species were present year around as juveniles but peaked in summer and autumn at both sites.

\section{DISCUSSION}

Estuaries worldwide have been linked with the larval and juvenile stages of marine organisms, particularly of those species important to fisheries. However, 

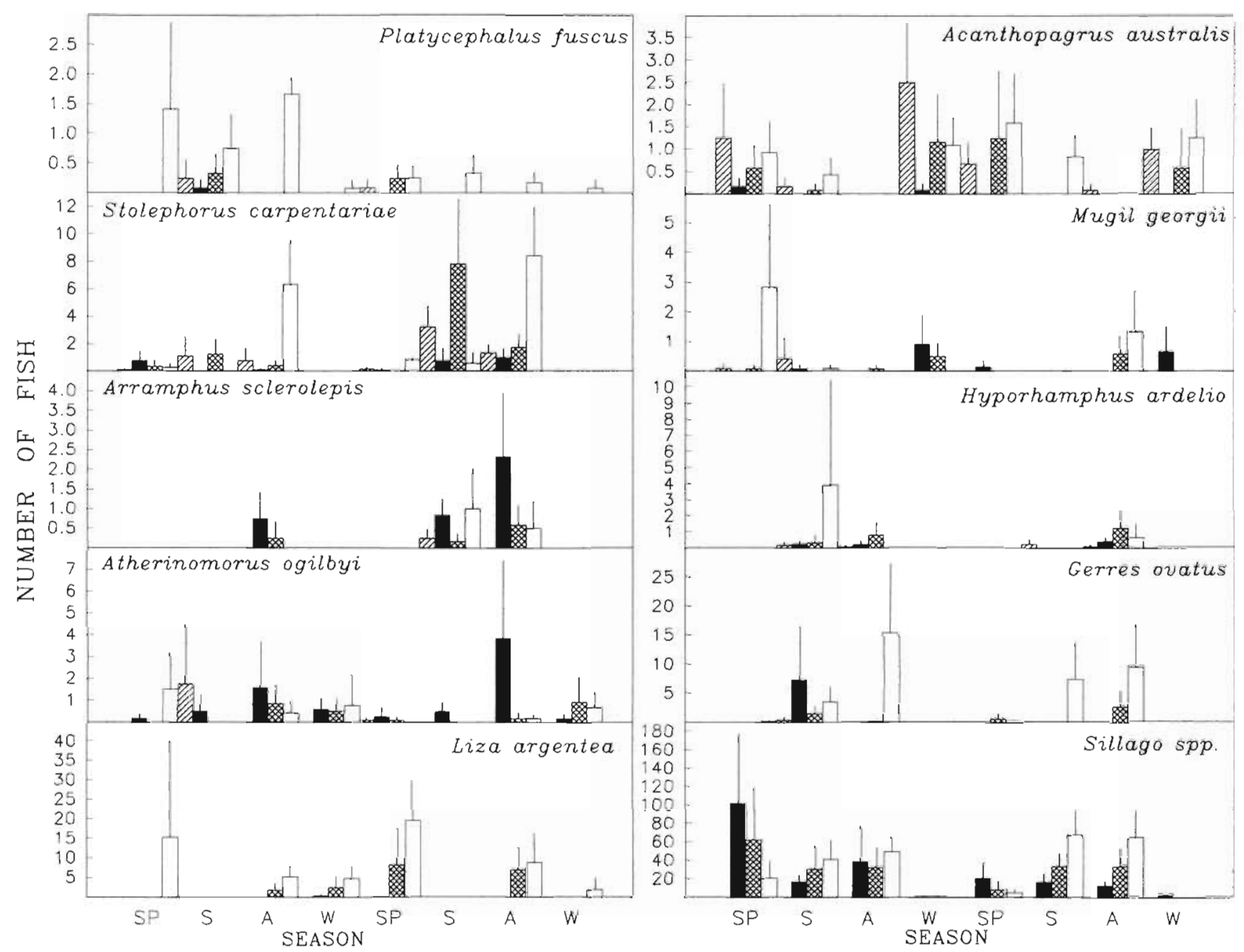

Fig. 9. Mean seasonal abundances $\pm 1 \mathrm{SE}$ for the 10 most abundant species at Deception Bay that were not restricted to 1 habitat. Diagonal lines: seagrass; solid: mudflat; cross hatch: pneumatophores; empty: mangrove forest

details of between-habitat differences in this nursery role have usually not been explored. The distinct habitats within an estuary may well form distinct communities of juvenile fish in terms of species richness, abundance and the number of species of commercial significance. In the few cases where habitats have been compared, distinct habitat-specific communities have been identified (Robertson \& Duke 1987, Morton 1990). Moreover, it appears that habitats are not equal in species richness and abundance, with vegetated substrata being superior (Miller \& Guillory 1980, Talbot \& Able 1984, Mcivor \& Odum 1986, Sogard \& Able 1991).

With the increasing rate of destruction of natural estuarine habitats for real estate, it is necessary to establish these differences to prioritise management options and conservation practices to ensure sustainability of estuarine systems and their valuable fisheries resources.

\section{Habitat comparison}

At the sites studied here, in subtropical eastern Australia, fish species formed distinct communities within seagrass, mudflat and mangroves habitats, with between habitat differences being especially prominent during summer months. Also, mangrove habitats harboured twice as many species of juvenile fish than in adjacent seagrass and mudflat areas.

The seagrass habitats at Fisherman Island and Deception Bay were dominated by small resident species and juveniles of nonresident species that are of little economic importance. This result supports earlier work in other Australian estuaries (Middleton et al. 1984, Pollard 1984, Blaber et al. 1992), that seagrass beds, in general, are far more important as nursery areas for commercial crustacean species than for fishes. Seagrass habitats play a nursery function for fishes but compared to the gross abundance of juve- 
niles and number of economically important species that occur in mangrove forests, their nursery importance is diminished.

The mudflat habitat of Fisherman Island and Deception Bay showed little or no seasonal pattern throughout the study and contained many of the same species that occurred in the mangrove forests and seagrass beds. Only 1 species, Callionymus calcaratus, was entirely mudflat specific. As found in other estuaries, most fish may occupy the mudflat as a transient habitat during each tidal cycle (Chong et al. 1990) so that the type and number of species found depend on the height of the tide. The mudflat is likely to be particularly utilised as the tide recedes, as fish move into other habitats at low tide when the mangrove habitat is unavailable.

During high tide many species were utilising both the mudflat and mangrove forest environment, however fish on the mudflats were generally larger than the same species in the mangroves (Laegdsgaard \& Johnson unpubl.). The mudflats may therefore represent a transition from the juvenile nursery habitat to the adult offshore habitat with ontogenetic growth. It has been demonstrated that juveniles grow rapidly in mangrove estuaries compared to other inshore marine habitats (Pinto 1988), and with increased size move on to different habitats.

The mangrove forest is only available as a nursery at high tide twice a day and at low tide the juveniles must reside elsewhere. It has been suggested that juveniles may take advantage of submerged aquatic vegetation during this time as observed in salt marsh communities (Rozas \& Odum 1987). At Deception Bay, the large creek running through the mangroves has much submerged vegetation and many of the juveniles could seek refuge here at low tide. This creek has the added advantage of being separated at low tide from the main water body but is never completely dry, thus providing a shallow sheltered habitat during low tide. At Fisherman Island small fish were observed in the shallows at low tide and presumably did not venture into the deeper waters of the shipping channel. At Fisherman Island there are also subidal weed beds that may be utilised for cover The question of the habitat utilisation of juvenile fish at low tide requires further research.

\section{Community structure}

The total of 53 species of juvenile fish caught at the 2 sites in Moreton Bay is slightly lower than species richness reported for other sites in the region 65 species, Serpentine Creek, Stephenson \& Dredge 1976) and in other subtropical estuaries (64 species, South Florida;
Thayer et al. 1987). Overall, species richness is much lower than in tropical estuaries which harbour 2 to 3 times more species (e.g. Papua New Guinea, Liem \& Haines 1977; North Queensland, Robertson \& Duke 1990; Philippines, Pinto 1988).

Although they support fewer species, subtropical mangrove systems yield a higher proportion of species of commercial value (Bell et al. 1984, Claridge et al. 1986, Morton 1990). This was evident at the 2 sites in Moreton Bay where $71 \%$ of the most abundant species are of economic importance. The majority of the economically important species occurred in the mangrove forests with relatively few found in seagrass beds. It appears that seagrass beds worldwide harbour few economically important fish species (Heck \& Thoman 1984, Pollard 1984, Blaber et al. 1992). Of the 10 fish species harvested commercially in Moreton Bay, mullet, bream, summer whiting, winter whiting, tailor, flathead and gar appear to be dependent on the mangrove forests in that spawning of these species occurs in deeper water and early juveniles move into shallow mangrove areas, but not into other habitats. They utilise other habitats only when they become large enough to begin migration to the adult habitat

Deception Bay and Fisherman Island are separated in Moreton Bay by approximately $40 \mathrm{~km}$, and significant differences in community structure were evident between the sites. Fisherman Island had a greater species richness overall and twice the overall abundance of Deception Bay. The greatest differences were between the seagrass habitats at the 2 sites; species richness at Fisherman Island was greater than Deception Bay throughout the study whereas in the other habitats differences were dependent on season. Species richness in seagrass beds has been positively correlated with water depth and blade height (Blaber et al. 1992) and this may explain in part the greater species richness at Fisherman Island. Although the site is an area of increased industrial activity and is moderately polluted, mangrove forests are abundant and the biomass of Avicennia marina in the area is similar to that of communities elsewhere (Mackey 1993). The sediments have been shown to be nutrient enriched (Mackey et al. 1992) and this may have some effect on the number of juveniles at this site.

Differences in communjty assemblages among sites that are separated even by short distances have been reported elsewhere, and the magnitude of the dissimilarity may vary from year to year (Robertson \& Duke 1987, Loneragan \& Potter 1990). Since transport in the early stages of a fish's life is dependent on prevailing current and wind conditions, it is not surprising that among-site differences are particularly common for species with planktonic larvae (McNeil et al. 1992). Year to year differences can reflect differential recruit- 
ment patterns and spawning success of the adult populations. In this study, total catches at Fisherman Island increased markedly in the second year. A possible explanation is that rainfall in 1991/92 was particularly high, as evidenced by the appearance of freshwater species such as Gambusia affinis at Fisherman Island. Deception Bay received less rain during 1991/92 and as a consequence the catches for the 2 years at this site were similar

\section{Seasonality}

The seagrass habitat at Deception Bay showed little in the way of seasonal change in abundance which may have been due to the abundance of Pelates quadrilineatus year around. Fish abundances in the mangrove habitat however, along with mangrove and seagrass habitats at Fisherman Island, were highly seasonal with peaks in summer and lows in winter. Species richness in all habitats at both sites also demonstrated peaks in summer and lows in winter. Other estuarine areas have shown similar seasonality in abundance and species richness (Cain \& Dean 1976, Livingston 1976, Beckley 1984, Claridge et al. 1986).

Many fish species spawn during spring, which coincides with the influx of postlarvae and juveniles into estuarine areas in late spring/summer after their planktonic phase. It is not clear why postlarvae and juveniles move into estuaries but it has been demonstrated that they show preference for sheltered, shallow habitat (Russell \& Garrett 1983, Lenanton \& Potter 1987). This influx of juvenile fish at Deception Bay and Fisherman Island during summer increased the ratio of nonresident species to resident species from $1: 1$ to $2: 1$. By winter most species had vacated the estuaries and the number of resident and nonresident species became approximately equal. The nonresident species that remain throughout the winter have either a later spawning season, are capable of multiple spawnings or are those yet to leave from the summer peak.

\section{Importance of physical factors}

It remains unclear why juveniles of so many fish species prefer mangrove forests over adjacent habitats. Odour, temperature, salinity, turbidity and pH can act as attractants for late stage larvae, and these larvae can exercise choice in riding favourable currents to nursery areas (Boehlert \& Mundy 1988, Miller 1988). Clear relationships between turbidity and distributions have been demonstrated, with juvenile fish showing preference for turbid waters (Cyrus \& Blaber 1987). In
Moreton Bay, turbidity has been shown to be highest during summer and an important factor in attracting fish to Deception Bay as opposed to the eastern side of Moreton Bay where turbidity is much lower (Blaber \& Blaber 1980). However, within the estuaries studied here, turbidity, salinity and temperature did not vary greatly among mudflats, seagrass or mangroves at either site. Other factors must therefore be responsible for differences in the types of juvenile fish present and their abundance within estuaries. There are many hypotheses as to what these factors might be, such as food availability and/or decreased predation risk, which are the subject of current investigation (Laegdsgaard \& Johnson unpubl.).

\section{CONCLUSIONS}

It is clear that the mangrove forests of Deception Bay and Fisherman Island are important nurseries for many of the commercially harvested fish of Moreton Bay. The limited function of seagrass beds as nursery sites for fish is insignificant when compared to the importance of mangroves. While variability among sites and years occurred, trends were similar and indicated the importance of mangrove forest sites within Moreton Bay as nursery areas. Since the majority of juveniles in mangroves are of economically important species, and that they appear to preferentially inhabit mangrove forests, these habitats must be conserved to ensure the continued viability of fisheries resources in Moreton Bay.

Acknowledgements. This research was funded by a University of Queensland Research Grant to P.L. and C.J. Thanks go to the general staff in the Department of Zoology at the University of Queensland for assistance throughout. Mrs B. Laegdsgaard assisted with net construction which was greatly appreciated. Without all the volunteers who aided with less than glamorous field collections, this project would not have been completed or been near as much fun; thank you most of all.

\section{LITERATURE CITED}

Austin HM (1971) A survey of the ichthyofauna of the mangroves of western Puerto Rico during December, $1967-$ August, 1968. Carib J Sci 11(1-2):27-39

Beckley LE (1984) The ichthyofauna of the Sundays Estuary, South Africa, with particular reference to the juvenile marine. Estuaries 7(3):248-258

Bell JD, Pollard DA, Burchmore JJ, Pease BC, Middleton MJ (1984) Structure of a fish community in a temperate tidal mangrove creek in Botany Bay, New South Wales. Aust J mar Freshwat Res 35:33-46

Beumer JP (1978) Feeding ecology of four fishes from a mangrove creek in North Queensland, Australia. J Fish Biol 12:475-490 
Blaber SJM (1980) Fish of the Trinity Inlet system of North Queensland with notes on the ecology of fish faunas of tropical Indo-Pacific estuaries. Aust J mar Freshwat Res 31:137-145

Blaber SJM, Blaber TG (1980) Factors affecting the distribution of juvenile estuarine and inshore fish. J Fish Biol 17 $143-162$

Blaber SJM, Brewer DT, Salinı JP (1989) Species composition and biomass of fishes in different habitats of a tropical northern Australian estuary: their occurrence in the adjoining sea and estuarine dependence. Estuar coast Shelf Sci 29:509-531

Blaber SJM, Brewer DT, Salini JP, Kerr JD, Conacher C (1992) Species composition and biomasses of fishes in tropical seagrasses at Groote Eylandt, Northern Australia. Estuar coast Shelf Sci 35:605-620

Blaber SJM, Young JW, Dunning MC (1985) Community structure and zoogeographic affinities of the coastal fishes of the Dampier Region of North-western Australia. Aust J mar Freshwat Res 36:247-266

Boehlert GW, Mundy BC (1988) Roles of behavioural and physical factors in larval and juvenile fish recruitment to estuarine nursery areas. Am Fish Soc Symp 3:51-67

Cain RL, Dean JM (1976) Annual occurrence, abundance and diversity of fish in a South Carolina intertidal creek. Mar Biol 36:369-379

Chong VC, Sasekumar A, Leh MUC, Cruz RD (1990) The fish and prawn communities of a Malaysian coastal mangrove system, with comparisons to adjacent mudflats and inshore waters. Estuar coast shelf Sci 31:703-722

Claridge PN, Potter IC, Hardisty MW (1986) Seasonal changes in movements, abundance, size composition and diversity of the fish fauna of the Severn Estuary. $J$ mar biol Ass UK 66:229-258

Cyrus DP, Blaber SJM (1987) The influence of turbidity on juvenile marine fishes in estuaries. Part 2. Laboratory studies, comparisons with field data and conclusions $J$ exp mar Biol Ecol 109:71-91

Ferrell DJ, Bell JD (1991) Differences among assemblages of fish associated with Zostera capricorni and bare sand over a large spatial scale. Mar Ecol Prog Ser 72:15-24

Field CD, Dartnoll AJ (eds) (1987) Mangrove ecosystems of Asia and the Pacific: status, exploitation and management Proc Res Develop Sem AIMS, Townsville

Heck KL Jr, Thoman TA (1984) The nursery role of seagrass meadows in the upper and lower reaches of Chesapeake Bay. Estuaries 7:70-92

Hyland SJ, Butler CT (1988) The distribution and modification of mangroves and saltmarsh-claypans in southern Queensland. Queensland Department of Primary Industries Information Ser Q189004

Johnson CR. Field CA (1993) Using fixed-effects model multivariate analysis of variance in marine biology and ecology. Oceanogr mar Biol A Rev 31:177-221

Lenanton RCJ, Potter IC (1987) Contribution of estuaries to commercial fishenes in temperate Western Australia and the: concept of estuarine dependence. Estuaries 10 (1): 28.35

Liem DS, Ffaines AK (1977) The ecological significance and economic importance of the mangrove and estuarine communities of the Gulf Province, Papua New Guinea. Purari River (Wabo) hydro-electric scheme, Environ Stud 3:1-35

Little MC, Reay PJ, Grove SJ (1988) The fish community of an East African mangrove creek. J Fish Biol 32:729-747

Livingston RJ (1976) Diurnal and seasonal fluctuations of organisms in a north Florida estuary. Estuar coast mar Sci $4: 373-400$
Loneragan NR, Potter IC (1990) Factors influencing community structure and distribution of different life-cycle categories of fishes in shallow waters of a large Australian estuary, Mar Biol 106:25-37

Mackey AP (1993) Biomass of the mangrove Avicennia marna (Forsk.) Vierh. near Brisbane, south-eastern Quecnsland. Aust J mar Freshwat Res 44:721-725

Mackey AP, Hodgkinson M, Nardella R (1992) Nutrient levels and heavy metals in mangrove sediments from the Brisbane River, Australia. Mar Pollut Bull 24:418-420

McIvor CC, Odum WE (1986) The flume net: a quantitative method for sampling fishes and macrocrustaceans on tidal marsh surfaces. Estuaries 9:219-224

McNeil SE, Worthington DG, Ferrell DJ, Bell JD (1992) Consistently outstanding recruitment of five species of fish to a seagrass bed in Botany Bay, NSW. Aust J Ecol 17:359-365

Middleton MJ, Bell JD, Burchmore JJ, Pollard DA, Pease BC (1984) Structural differences in the fish communities of Zostera capricorni and Posidonia australis seagrass meadows in Botany Bay, New South Wales. Aquat Bot 18: $89-109$

Miller C (1988) Physical processes and the mechanisms of coastal migrations of immature marine fishes. Am Fish Soc Symp 3:68-76

Miller C, Guillory V (1980) A comparison of marsh fish communities using the Wegener ring. Proc A Conf Southeast Assoc Fish Wildl Agencies 43:223-233

Morton RM (1990) Community structure, density and standing crop of fishes in a subtropical Australian mangrove area. Mar Biol 105:385-394

Pinto L (1988) Population dynamics and community structure of fish in the mangroves of Pagbilao, Philippines. J Fish Biol 33(A):35-43

Pollard DA (1984) A review of ecological studies on seagrassfish communities, with particular reference to recent studies in Australia. Aquat Bot 18:3-42

Potter IC, Loneragan NR, Lenanton RCJ, Chrystal PJ, Grant CJ (1983) Abundance, distribution and age structure of fish populations in a western Australian estuary. $J$ Zool Lond 200:21-50

Quinn NJ (1980) Analysıs of temporal changes in fish assemblages in Serpentine Creek, Queensland. Environ Biol Fish 5 (2): 117-133

Quinn RH (1993) Fisheries resources of Moreton Bay. In: Greenwood JG, Hall NJ (eds) Future of marine science in Moreton Bay. School of Marine Science, University of Queensland, p 157-158

Robertson AI, Duke NC (1987) Mangroves as nursery sites: comparisons of the abundance and species composition of fish and crustaceans in mangroves and other nearshore habitats in tropical Australia. Mar Biol 96:193-205

Robertson AI, Duke NC (1990) Mangrove fish-communities in tropical Queensland, Australıa: spatial and temporal patterns in densities, biomass and community structure. Mar Biol 104:369-379

Rozas LP, Odum WE (1987) Use of tidal freshwater marshes by fishes and macrofaunal crustaceans along a marsh stream-order gradient. Estuaries 10(1):36-43

Russell. DJ, Garrett RN (1983) Use by juvenile barramundi Lates calcarifer (Bloch) and other fishes of temporary supralıttoral habitats in a tropıcal estuary in northern Australia. Aust J mar Freshwat Res 34:805-811

Sogard SM, Able KW (1991) A comparison of eelgrass, sea lettuce macroalga, and marsh creeks as habitats for epibenthic fishes and decapods. Estuar coast Shelf Sci 33: $501-519$

Stephenson W. Dredge MCL (1976) Numerical analysis of fish 
catches from Serpentine Creek. Proc R Soc Queensld $87: 33-43$

Talbot CW, Able KW (1984) Composition and distribution of larval fishes in New Jersey high marshes. Estuaries 7(4a): $434-443$

Thayer GW, Colby DR, Hettler WF Jr (1987) Utilisation of the red mangrove prop root habitat by fishes in south Florida. Mar Ecol Prog Ser 35:25-38

This article was presented by D. M. Alongi (Senior Editonal Advisor), Townsville, Australia
Wright JM (1986) The ecology of fish occurring in shallow water creeks of a Nigerian mangrove swamp. J Fish Biol 29:431-441

Yanez-Arancibia A, Amezcua-Linares F, Day JW (1980) Fish community structure and function in Terminus Lagoon, a tropical estuary in the Southern Gulf of Mexico. In Kennedy $V$ (ed) Estuarine perspectives. Academic Press Inc, New York, p 465-4821

Manuscript first received: December 22, 1994

Revised version accepted: March 27, 1995 